\title{
Hypermodern Hearts: What Makes Them Suffer and Become IIl?
}

\author{
Suzana de A. Paiva1', Joel S. Giglio², Carmen Silvia P. Lima ${ }^{3}$, Francisco Silveira ${ }^{4}$ \\ ${ }^{1}$ Department of Medical Psychology and Psychiatry, Faculty of Medical Sciences, State University of Campinas, \\ UNICAMP, Campinas, Brazil \\ ${ }^{2}$ Department of Medical Psychology and Psychiatry, Faculty of Medical Sciences, State University of Campinas, \\ UNICAMP, Campinas, Brazil \\ ${ }^{3}$ Clinical Oncology Service, Department of Internal Medicine, Faculty of Medical Sciences, State University of \\ Campinas, UNICAMP, Campinas, Brazil \\ ${ }^{4}$ Department of Cardiology, SEMPER Hospital, Belo Horizonte, Brazil \\ Email: spaiva@ecos.com.br
}

Received 8 April 2015; accepted 2 June 2015; published 5 June 2015

Copyright (C) 2015 by authors and Scientific Research Publishing Inc.

This work is licensed under the Creative Commons Attribution International License (CC BY). http://creativecommons.org/licenses/by/4.0/

(c) (;) Open Access

\section{Abstract}

In this research, we highlight the hypermodern individual, the ways he lives in the contemporary world and the psychosocial determinants involved in illness. We aim to reveal the impact of traumatic life events and the senses and meanings given by the patients to their pathologies. The research was carried out at two private hospitals in Brazil, in the years 2010 and 2011. The study is based on a qualitative method, through a semistructured interview with open-ended questions and the drawings-stories procedure, in an intentional sample, closed by saturation, during the period of hospitalization and right after leaving hospital (15 to 30 days). We used a qualitative content analysis and analysis of drawings under the framework of Analytical Psychology. Seven female patients that underwent surgery were the subjects of this research: two with Myocardial Infarction, one with Takotsubo Syndrome, three with Breast Cancer and one with both pathologies. Through the analysis of the interviews and the symbols presented in the drawings, we observed demands for hyperformance and hyperfection, linked with illness, when in excess. Traumatic life events, job stress, reactions to loss, and death of loved ones without the possibility of psychological elaboration may cause fragility and a lowering of the capacity of the immune system to react, causing damage to health. Through the symbolic trajectory of life, spontaneously presented in the drawings, we observed the three types of thinking in the structure of the psiqué which formed the basis for mental equilibrium: rational, symbolic and mythological. Infarction and breast cancer cause different impacts on women's lives. Knowing how to deal with stressful events and being conscious of the meanings given to illness may contribute to making a better or worse experience in life. Such knowledge may be crucial for both primary and secondary prevention. 


\section{Keywords}

\section{Qualitative Research, Hypermodernity, Acute Myocardial Infarction (AMI), Breast Cancer, Psychoneuroendocrinoimunology}

\section{Introduction}

\section{"Know thyself"}

Delphi Oracle

The quest for knowledge, especially self-knowledge, is part of human history, as well as the search for health and, more recently, the valorization of the quality of life and the measures taken to ensure it, in an attempt to avoid illness, prolong life and lead a healthy life. The first phrase of the Delphi Oracle says: "Know thyself", and the second warns: "But nothing in excess." This is a very appropriate advice for the hypermodern age since, currently, individuals operating in the panorama of hypermodernity experience the "hyper" dimension, in the sense of excess, in several aspects of their life, almost in an imposed manner.

Hyper(per)formance is a term created by Aubert [1] to express the need for performance up to a higher and extreme level, imposed by hypermodern society. Hyperformance and hyperfection, the need to outdo themselves, according to this author, will lead individuals to test, constantly, their own limits [2] [3].

Hypermodern society has been exhibiting characteristics of a new relationship with time and with the imagination of individuals who end up feeling inadequate and with the need to act increasingly faster at all costs [1] [4]. According to Aubert [4], we live in a society "sick in regards to time and urgency", in which urgency and anguish create a constant pressure on our physical and psychic equilibrium. We live subjected to the tyrannies of time, which are currently translated by a practice based on an invasive ideology, that is, the ideology of the urgent action.

The hypermodernity of individuals imposes on them the need to outdo them in every sense all the time, more specifically, in the physical, intellectual, professional and emotional sense. Even when dying, what is important is outdoing themselves, and what is important is transcending their human condition. Aubert [4] articulates one of the maxims of the hypermodern individual, which is living the most in an instant, in an attempt to evade death. This author notes that death is always on the horizon, and that, currently, the intensity of the relationships lived in the present makes every moment seem to be like a little piece of eternity. Thus, the search for intensity replaces the search for eternity.

In the panorama of hypermodernity, the offers, opportunities and competitive challenges show the hypermodern individual in limit situations and, therefore, in situations of illness. These manifestations are connected to stress, which is considered as a risk factor for the occurrence of acute myocardial infarction (AMI) and breast cancer (BC), as well as depression, and, consequently, smoking, hypertension, a sedentary life, obesity, negative emotions, psychosocial factors, etc. [5]-[14].

Coronary artery disease (CAD) is considered as lifestyle pathology. But if people become aware of this and change the lifestyle habits that are considered as those that cause illnesses, they may live longer. According to data from the DATASUS/MS [Unified Health System Computer Department/Ministry of Health], in Brazil, "in the year of 1998 alone, the mortality rate for illnesses of the circulatory system reached 256,333 cases. These are the illnesses with the highest mortality rate among us, being responsible for almost half of the deaths occurring in individuals over 64, with ischemic heart diseases standing out, and AMI in particular, with 57,940 deaths" [15].

In the United States, one in every 3 women will die of coronary heart disease (CHD), the number one killer of women [16]. In Australia [17], coronary artery disease remains the leading cause of mortality in men and women. According to Lukkarinen and Kyngäs [18], cardiovascular disease is the leading cause of death in the world and will remain so by the year 2020. In Europe, there are approximately 2 million cardiovascular deaths every year, and approximately $20 \%$ of European men and women die from this disease. In Finland approximately 50,000 persons are diagnosed for coronary artery disease (CAD) every year [18].

There is an enormous amount of literature on psychological stress and cardiovascular disease [19]. Dimsdale [20] explains the ramifications of stress in terms of the effects of acute versus long-term stressors on cardiac functioning. Acute stressor studies are discussed in terms of disasters like earthquakes and in the context of ex- 
perimental stress physiology studies. And studies of chronic stressors are discussed in terms of job stress, marital unhappiness and burden of caregiving. From all of these studies, this author points out the stressors' contribution to diverse pathophysiological changes including sudden death, myocardial infarction, myocardial ischemia and wall motion abnormalities, as well as to alterations in cardiac regulation as indexed by changes in sympathetic nervous system activities and hemostasis [20].

In the work environment, Bosma et al. [21] examined the association between two alternative job stress models: the effort-reward imbalance model and the job strain model-and the risk of coronary heart disease. Job strain and high job demands were not related to coronary heart disease; however, low job control was strongly associated with new disease. Another study by Peter and Siegrist [22] indicate that job strain and effort-reward imbalance at work define specific conditions of chronic work stress that are associated with an elevated risk of coronary heart disease. In Japan, some studies suggest that the coronary disease-prone behavior pattern may include a job-centered lifestyle and social dominance [23].

Different life events, considered impacting, such as work related and emotional stress, bereavement, separation, financial losses, among others, affect the psycho-emotional balance of individuals. Studies and researches in the field of Psychoneuroendocrinoimmunology (PNEI) prove that what affects humans emotionally can have consequences for their physical health and their essence in general, determining diseases such as AMI and BC.

Psychoneuroendocrinoimmunology (PNEI): Mind and body in one single heart

Currently, the hypothesis of the susceptibility to certain non-infectious chronic pathologies, such as, cancer, to psychosocial stress, as is the case of the emotional dysthymias, anxiety, distress and depression, through the mediation of the immunological system, has already been established [24]-[30]. Neuropsychological, psychosocial and neuroanatomical studies have demonstrated its role in increasing or decreasing immune/allergic responses and reveal the bidirectional communication between the neuroendocrine and neurological systems and the immune system. The hypothalamic-pituitary-adrenal (HPA) axis and the sympathetic adrenal medullar system are the primary neuroendocrine and neuronal components of stress responses [31].

With Psychoneuroendocrinoimmunology (PNEI) studies, the existence of a psychological influence on cancer growth is observed, and it has been possible to establish that the psychological influence is mediated by the immune system. According to Messina et al. [32], "recent immuno-oncological studies, have shown that within the group of CD4 + cells, which play a fundamental role in the generation of anticancer immunity, there is a subtype of cells that in contrast mediates the suppression of the anticancer immunity, the so-called T-regulatory cells (T-reg), identified as CD4 + CD25 + cells" (p. 75). The study suggests that self-punishment may inhibit the generation of an effective anticancer immune response by stimulating the activation and proliferation of T-reg lymphocytes, which in turn stimulate tumor dissemination by suppressing anticancer immunity [32].

Psychoneuroimmunology is a new and complex field of medicine. "Neurons "talk" to the lymphocytes, and vice-versa, opening paths and delimiting the borders between life and death" [33].

The term Psychoneuroimmunology was introduced by Robert Ader in 1981 to define the field of science that studies the interaction between the central nervous system (CNS) and the immunological system from the perspective of the complexity of the reactions of organic adaptation to situations of alertness and danger (flight or fight) [31]. This field tries to examine the effect of the psychological factors to the nervous, hormonal and immunological systems, such as, the effects of stress in our mind and body. Its base is interdisciplinary, with the objective of bringing the fields of neuroscience and immunology together.

According to Reynaert, Libert and Pascal [34], the fact that the cellule is part of a complex system, which involves several communication and interaction mechanisms, and that the second great question about carcinogenesis is based on the weakening of the organism's defenses due to hormonal and immunological factors is well known and clearly established [34]. For this author, psychoneuroendocrinoimmunology establishes itself as the first clue for the interdisciplinary mediation that is capable of sustaining the relationship between psychology and cancer [34]. However, the relationship between psychological factors and cancer are highly complex, because they involve the biological, psychological and sociological systems in circular changes. It is currently known, through scientific research, that external factors such as stress, depression or the absence of social support significantly influence the immune system elements influencing the emergence or evolution of cancer [34].

Current researches on infarction and breast cancer show some significant differences when compared to older ones, most likely due to the lifestyle of the population which operates in this panorama of hypermodernity. Young patients who suffered infarctions, even without having genetic alterations or a history of cardiovascular disease in the family, but who smoke, have high levels of stress and are sedentary, are suffering myocardial infarction increasingly early [34]. 
CAD has been assumed to be a problem of men, but since 1975, the incident of CAD has also been increasing among women [18].

With the aging of the current generation, an increase of $93 \%$ in the prevalence of heart diseases between the years of 2000 and 2050 , followed by an increase of the mortality rate of approximately $128 \%$ over the same period of time, is expected [36].

A progressive increase in the occurrence of breast cancer in the world has also been observed. According to Lima [37], among the several factors identified as being responsible for the increase in the number of cancer cases, the individuals' greater exposure to carcinogens and the increase in the life expectancy of several populations stand out. The distribution of the different types of cancer indicates that Brazil is undergoing a transition from a developing country to a developed one, since a significant increase in the number of cases of breast, prostate, colon and rectal cancer can be observed [37].

In Brazil, breast cancer is the most frequent malignant neoplasia among women [38].

To Reynaert et al. [34], the repression of emotions and not caring about oneself are personality traits that are associated with cancer.

Common questions, according to researches performed in the Broussais and Georges Pompidou hospitals in Paris:

Did stress cause my cancer? Did bereavement cause my cancer or aid the relapse? Did my personality or emotions cause the cancer? Can my state of mind affect the evolution of my tumor? [39].

In our clinic in Belo Horizonte, MG, Brazil, we commonly hear:

Is God punishing me? Why? What did I do?

Guilt, loss, grief, attitudes, personality traits, emotions, all these aspects are present in the questions and in the attempts to understand the disease and its relation to life events.

In this study our gaze falls upon patients who experienced illness, surgery and hospitalization. Our goals were to try to reveal the impact of traumatic life events and the meanings given by the patients to their pathologies. The knowledge and the truths acquired through the procedures of the research can bring enlightenment to the work of professionals, to the family members and even to the patients themselves, and, ultimately, to the clinical hospital practice.

\section{Patients and Methods}

\subsection{Clinical-Qualitative Research Methodology Applied to the Health Care Area}

The qualitative research seeks the "experienced emotion" and identifies the psychological meaning of the individual's expressions. For Turato [40], the meanings related to the phenomena are central to qualitative researchers. "Trying to capture them by listening to and observing the research subjects, as well as providing interpretations, are the main goals" [40]. As a particularization and refinement of the generic qualitative methodology, according to this author, the clinical-qualitative methodology is conceived as the study and the construction of the epistemological limits of a certain qualitative method particularized in health care settings.

\subsection{Methodological Resources}

Semistructured interviews and the drawings-stories procedure (D-S) [41]. The interviews and the procedure were performed in the post-surgery phase, during the period of hospitalization and right after leaving hospital (15 to 30 days).

\subsection{Patients}

There are seven women patients, three who suffered an AMI, one with takotsubo syndrome, a new heart syndrome mimicking acute myocardial infarction [42] [43], another three with BC, and one patient who had an infarction after her second $\mathrm{BC}$ surgery, consequently with both of the researched pathologies.

\subsection{Procedure}

From July to December 2010, in a sequential manner, BC and AMI patients who had been referred for surgery were selected. The research subjects were referred by their respective physicians. Both procedures were performed by the first author of the paper and the research [44]. 
The sampling method used was theoretical saturation. The group was closed when the patients' discourses showed significant meanings for the understanding of the theme and therefore did not add new information to the research.

\subsection{Data Analysis and Interpretation}

An analysis of the content of the interviews theoretically based on Bardin [45] was performed, as well as a clinical analysis and the interpretation of the drawings-stories (D-S), based on Trinca [46].

The drawings-stories procedure is a diagnostic process that seeks to find a meaning for the set of information available, take what is relevant and meaningful in the personality, empathically make emotional connections and also understand the deep motives in someone's emotional life, highlighting the emotional dynamics of the unconscious processes [46]. The application technique is based on an invitation to further the knowledge of the psychic life through free association. A series of five free drawings are requested, in sequence, each stimulating a story. Then the questioning phase follows, with further clarifications and a request to give a title to the production. The sequential reiteration of five production units does not result in isolated units, but in a continuous communication that serves the purposes of the whole [41].

\section{Results}

\section{A. Interviews' analysis categories \\ 1. Painful separations}

-"I went through too many separations! Painful... separations."

About the first separation, the patient reports that she helped her husband study, working a lot, and in the end she didn't attend his graduation. He went with the other woman. She felt betrayed and hurt. She divorced him when her son was only three-years-old. Regarding her other two relationships she reports that:

"My second husband died. It was a true love; which lasted for 9 years."

Regarding her third husband she says:

"I had surgery and the guy vanished."

She confirmed the breast cancer diagnosis to him by phone and he never showed up again, thus ending a six years relationship. After the interview, by phone, she wondered and suggested this as a theme to be researched:

"Maybe we psychologists have the tendency to place everything on the emotional plane? Couldn't the medicine, Tamoxifen, have also contributed to the AMI? I believe it was both the emotional duress and the Tamoxifen that caused my infarction." (Patient 1)

-The feeling of abandonment, with the separation:

"My father left us, abandoned our home when I was only four."

The patient's father left her mother when she was four. She remembers him. When her father returned she was seventeen. He was sick, with prostate cancer.

"My mother forgave him and took care of him." (Patient 5)

\section{Death of loved ones. Unworked-through grief}

One of the questions of the interview was aimed at the cause attributed to the cardiac event or breast cancer, in the patients' opinion.

-"My son's death, at 25." "I'm sorry, I cry a lot." "Could it also have been the beach's radioactive sand? I was in Vitoria." (Patient 2)

-"The death of my five-year-old sister. The medicine she was given wasn't medicine...it was the poison for the animals. It was a mistake." "Very sad..." The patient was seven at the time (Patient 3)

-"My husband's death. I can't imagine life without my husband." "He was everything to me!" (Patient 6)

-"My mother's death four years ago." "The first year was horrible, I just cried."

"During the first year I just cried, without any will to leave my bed. Despondency." (Patient 01)

\section{Stress in professional and love life}

-"I was too stressed at work." "There were too many demands, without a good personal and financial return, one that was satisfying."

This patient also reports problems she had with her business partner, when they had a small business:

"I was very hurt; my partner betrayed me. On top of it, she was my sister-in-law."

She also had a lot of problems with her son: 
"I believe that the fight I had with my son accelerated the heart attack."

The patient says she is a crier, she is sincere and emotional.

"Concerned about my children. AMI changes life a LOT. There was too much love and repression, I repressed a lot of stuff." (Patient 3)

-"The infarction? A fatality!"

The patient suffered her first AMI at 25, the year she got married. Then she got divorced.

"Settled life! Interruptions. That made me settle. The fear of not finishing, of having to stop, discouraged me a lot."

She was subjected to 18 hospitalizations. She experienced constant stress and ruptures of her emotional and work relationships due to the hospitalizations, weakening her psychic-emotional state. Despite that, she deals with these events in regards to her health coldly, maybe as a defense mechanism:

"The infarction? I do not associate it to anything! Anything! I think it isn't related to anything! Some people have it, others don't. I had it." (Patient 7)

B. Drawings-Stories Procedure (The patients names are fictitious, due to professional secret)

1. Fatima's life story-AMI. stories and associations

Drawing number 1 -Of a peaceful countryside, in the field, with a healthy childhood which is followed by the struggle to achieve success, facing her father and the unknown, leaving a small town to a large city, still very young, the loneliness, the struggle to find a job, the effort to do a good job and be better. Searching for professional success. There is smoke coming from the house's chimney, symbolizing the alchemy of transformation which can happen now. Associations: her childhood Title: Peace.

Drawing number 2-The staircase represents her climb to success. Which is what the patient seeks: success, conquests, professional achievement. However, with a lot of effort, work. A black and white drawing, with a pink line at the top, maybe recalling hope. The staircase is very clear at the beginning and, at the end, the stroke is fragile. Associations: The effort that she has always had to make in her life to grow. Title: The staircase to freedom from personal objectives.

Drawing number 3-An auditorium with lots of people. A speaker. This is the phase she associates with the AMI. Of her self-imposed hyperformance, working several shifts, morning, afternoon and night, working with lots of people, giving lectures, facing the wear, stress, fatigue and the search for her self-imposed hyperfection, leading to the AMI. Associations: Her work, since she had to talk a lot and give many lectures to lots of people. It was good but stressing. She had a heart attack. When drawing the table, she ended up cutting the woman's head out, symbolizing the abandonment of the excessive rational thinking. Title: Good acquaintanceship lecture.

Drawing number 4-With the characteristic of coronary disease patients, related to the personality of heroes, she recovers her strength, with hope, which is symbolized by the "Vase of Hope", with colorful flowers and with "a well-supported base". Thus, moving forward, searching for accomplishments. Something needs to flourish. Associations: "My life now, as I want it to be; WITHOUT STRESS!" Title: Vase of hope.

Drawing number 5-The "Future, multi-colored rainbow", a metaphor of the place where she will find the pot of gold, a symbol of hope, conquest and futurity. In the trajectory of the hero who overcame her metron, she who was and is fearless, who carried the world on her shoulders, had the courage to go and search for her dreams, with the vital necessity for expression and accomplishment of her individual self. Associations: hope, confidence in herself. Title: Future rainbow.

\section{Fatima's life story-AMI (Figure 1-5)}

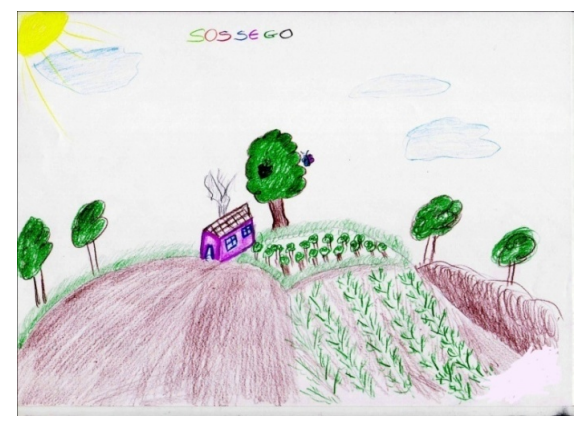

Figure 1. Patient's drawing number 1: Peace. 


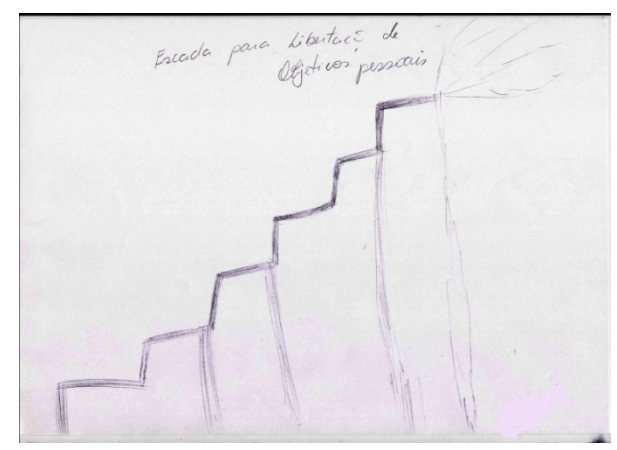

Figure 2. Patient's drawing number 2: The staircase to freedom from personal objectives.

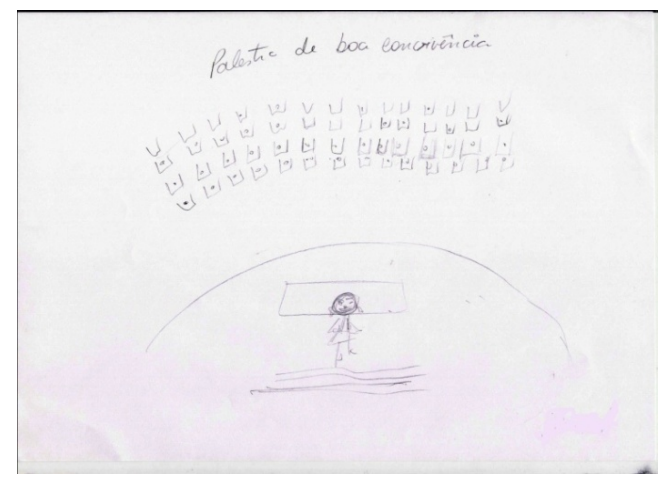

Figure 3. Patient's drawing number 3: Good acquaintanceship lecture.

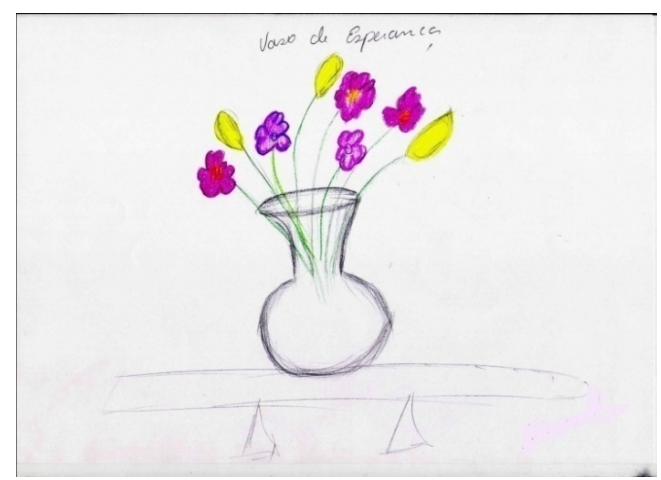

Figure 4. Patient's drawing number 4: Vase of hope.

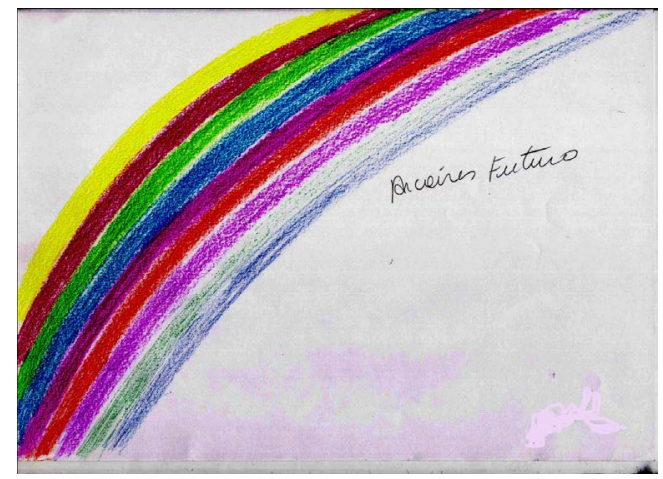

Figure 5. Patient's drawing number 5: Future rainbow. 


\section{Senses and meanings given to the $\mathrm{AMI}$ and to the $\mathrm{BC}$ by the patient Lena:}

Through the drawings, the patient expressed her feelings and the senses and meanings she attributed to the AMI and to BC. We will only use drawings number 1 and 3 here, from the patient's five drawings sequence.

\section{Drawing number 1}

"Get up! I have to be strong."

The duty of being strong, solid. Can't crumble:

"I was not born to be sick." [You were born to be what?] "Ah! I was born to live, live a lot! To dance, to love! I was always a very upbeat person; I wasn't a half-empty glass person. I live like this, with a lot of stuff." "The doctors would say: Your problem is emotional." "My heart is emotional."

\section{Drawing number 3}

The strong wind is associated with the illness. When I ask her: [which is the strongest wind?] She answers: "I can't explain; the cancer was found by a person, it wasn't something that was mine. It's like Saint Thomas, it looks like they are talking about you but you are outside it. With the heart attack, I started feeling sick at the office, I was alone, I went downstairs to buy an antacid, I took it and the "thing" wouldn't go away. I took a cab and went to the hospital. I had to fight to be seen, to be hospitalized, to do and electrocardiogram, since I warned them I was having a heart attack. So, it looks like... I saved myself!"

According to Lena, the cancer was harder. She was undergoing treatment and someone discovered the disease.

"It doesn't sound like me. I mean, being dependent on someone else. With the cancer, I was left without any action". "The cancer was that first shock that I could die..."

Regarding the heart attack, Lena believes that she was more effective.

"With the heart attack, it looks like... I saved myself! I have to pay, to do, to be well for my son's graduation... And then, after all that struggle, I relaxed! It seemed like: now I can die. Not that I wanted to, but I relaxed, I achieved everything..." "What I feel about the heart attack is this: I relaxed! He graduated, I held on for so long! I had to be so alive, that when I got there, after driving through the road, and arriving at the office, then I could die!" "Then I died" (laughs) "I got there, mission accomplished! Then, I had a heart attack!". "It was too much love and repression. I repressed a lot of stuff." "The heart, when I let myself die, I embraced to save myself and I did save myself!" "The cancer is a feeling. It was harder. I see the cancer as a depository, something that sedimented .. a depository. I was able to deal with the heart attack but not the cancer."

"The heart attack... I don't know, I think it was the relaxation of a mission managed. When I think about the heart attack, where it came from, that is exactly what I feel. I don't have to fight anymore. I think it was that relief. I was too emotional! I couldn't die because he was graduating to save lives, how can his mother die?"

However, earlier in the interview, she stated:

"The Cancer did not bring me down; what threw me to the floor was the heart attack. The heart attack made me feel old."

It seems that through the drawings she got in touch with aspects of her healing self and saw that she was capable of dealing with the heart attack. Title: Solidity (Figure 6 and Figure 7)

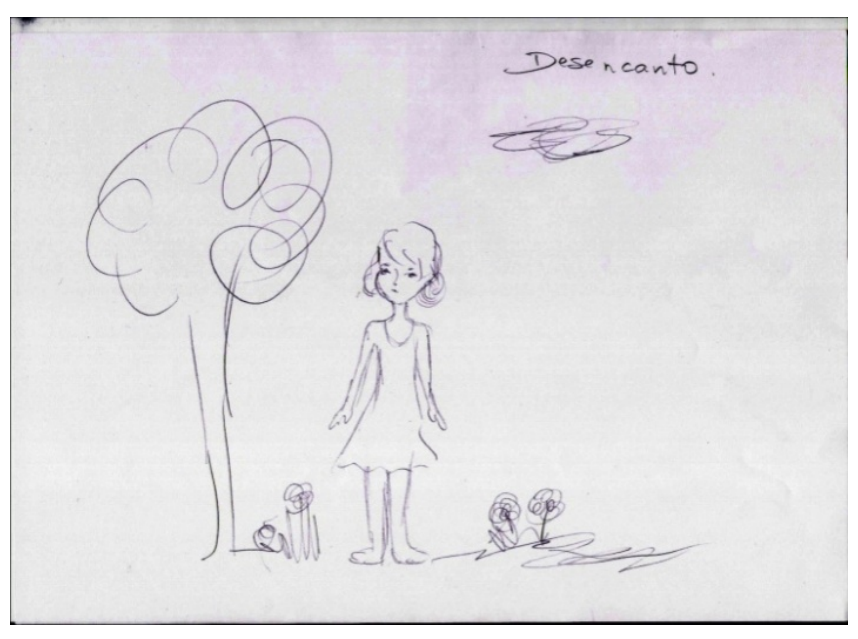

Figure 6. Patient's drawing number 1: Disenchantment. 


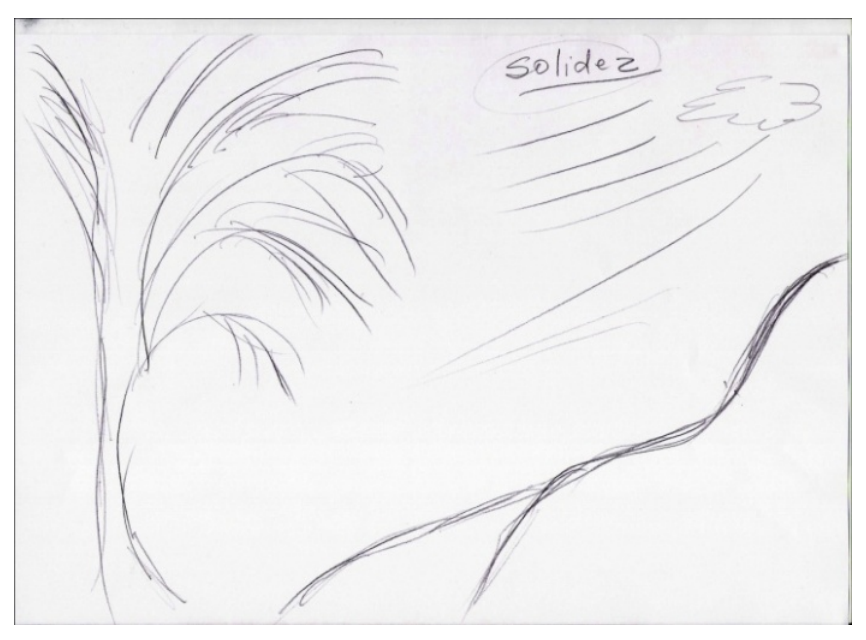

Figure 7. Patient's drawing number 3: Solidity.

3. Rational, symbolic and mythological-types of thought in the expressions of the fifth drawing. We will use the fifth drawing of the three first patients of this research: Lena, Ana and Fatima.

According to Brandão [47], in the structure of the psyche we find three types of thought which are fundamental for the psychic equilibrium: the rational, the symbolic and the mythological. We see all three types of thought in our psyche's structure, expressed spontaneously, in the patients' fifth drawing (Figures 8-10).

We performed a clinical evaluation and reached a prognosis in the psychic-emotional field based in the symbolic expressions of the fifth drawing, the moment in which we can notice a more intense and expressive deepening in regards to the elements of the unconscious. In Lena's Trajectory, BC and AMI, expressed through the five drawings, we see the following phases: Of disenchantment, the contact with herself, with strength, faith, light, until she achieved "a home and the search for family and professional achievements." Title for the drawing of a house: Victory! The patient with Cancer shows the importance of her family's support in her trajectory, in her first drawings, and the importance of love and faith in the drawing of the "rosary." Title for the drawing of the rosary: "The rosary that represents my faith". The patient with the AMI, goes from peace to struggle in her trajectory until she reaches the "rainbow". Title: "Future rainbow".

The three cases have structuring symbols that suggest a good prognosis regarding the psychic-emotional field.

The Hypermodernity aspects that we can consider as negative because they can hurt people's health, such as the pathologies of urgency, stress, self-imposed hyperformance and hyperfection, the unworked-through grief, separations, among others, are present in the life story of the patients.

We must also consider the positive aspects of hypermodernity, such as the advances of Modern Medicine. In Brazil, an example of these advances and of the mastery of cardiovascular surgeries is the technique of the coronary artery bypass grafting without cardiopulmonary bypass (CPB), through sternotomy and minimally invasive procedures, an accepted technique of myocardial revascularization [48]. The experiences proved in the quantitative researches and in the analyses of the results on the coronary artery bypass grafting without cardiopulmonary bypass during 15 years of experience [49], and in critical analysis during 23 years of experience [50], portray the surgeons' ability in seeking the improvement of cardiovascular medicine.

There are also great advances and victories in field of oncology. In a study about the influence of the polymorphism D104N of the COL18A1 gene, encoding endostatin, on the occurrence of sporadic breast cancer, the authors suggest that, for the first time, the homozygous $104 \mathrm{NN}$ polymorphism constitutes an important inherited determinant of the disease [51].

Regardless of the negative aspects of hypermodernity, we see values for family, home, love relationships and education still preserved in the patients' expressions, especially in the expressions in the patient with both AMI and BC. Expression of the concrete world, connected to rational thinking. With the rosary, a symbolic reference that sustains and gives strength, we also see the values of faith in the expressions of the patient with BC. And the values of the mythological thought, with the rainbow expressed by the AMI patient, an imaginative reference that is very important to the psychic equilibrium, suggesting the achievements of mythological heroes, such as the pot of gold coins found at the end of the rainbow. 


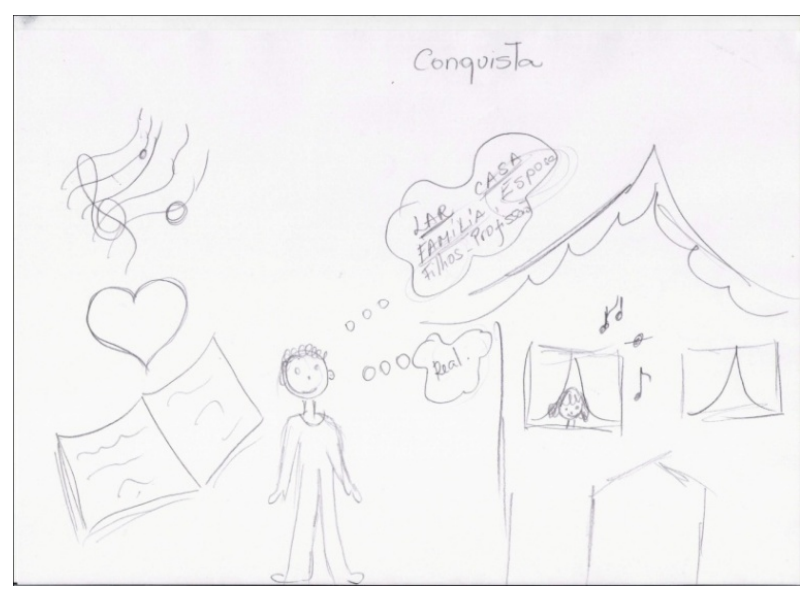

Figure 8. Patient's drawing number 5: "Victory"-Rational (Patient 1-Lena).

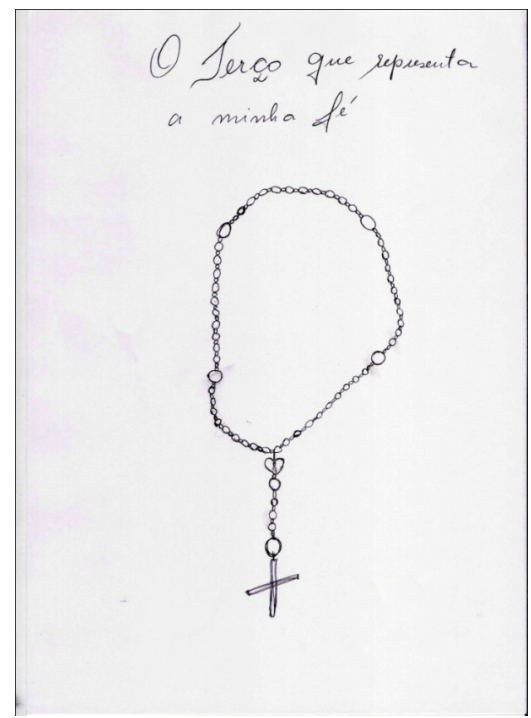

Figure 9. Patient's drawing number 5: "The rosary that represents my faith"-Symbolic (Patient 2-Ana).

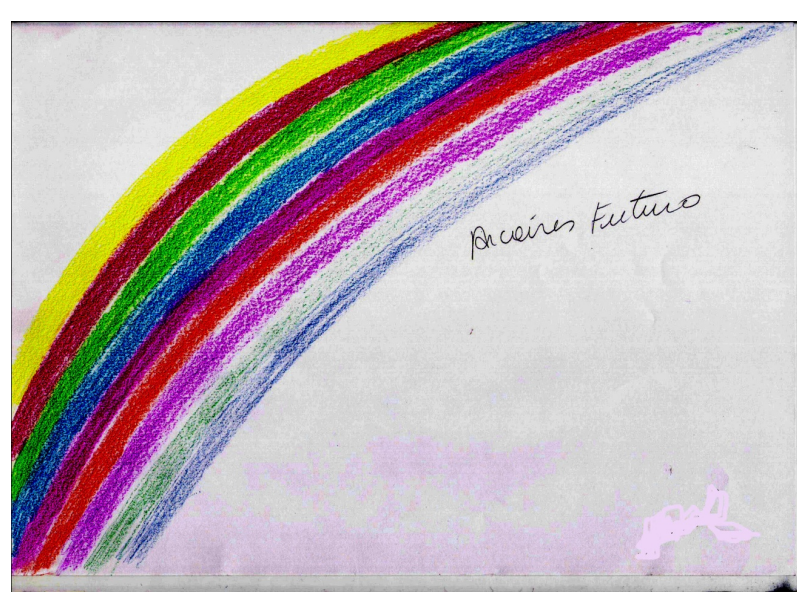

Figure 10. Patient's drawing number 5: "Future rainbow"Mythological (Patient 3-Fatima). 
Are these values endangered in our western society, as is wondered by many? This is our challenge, since, faced with the material presented and analyzed, we still see family, love, religious values preserved, as well as the values from mythology.

The expressions of art in these patients' spontaneous creations show that you can still dream of and desire a family, a home, education and love; you can still have faith, seek comfort in religion; and dream, imagine finding the pot of gold, symbolizing the achievements, with mythology. Structuring bases for the individual, despite being hypermodern!

We can see that the experiences with the AMI and the BC produced important meanings in these patients' lives. These reflections also suggest a care with the patients who intend to participate in a research. If, as stated by the patient Lena, the cancer is more silent than the heart attack, and therefore it was harder for her to deal with the cancer, prevention work becomes extremely important.

Lima [52] believes that science will find a cure for cancer. "Currently we act primarily in the prevention, early diagnosis and in the prompt administration of treatment." This author observes that the discovery of new chemotherapies and other medications for the various types of the illness, such as monoclonal antibodies and angiogenesis and epithelial cells proliferation inhibitors enable a higher percentage of cure, a longer survival rate or a better quality of life for the patients with cancer. "Several other medications are being currently investigated and we hope for new progress to be quickly obtained in this area" [52].

C. Life events-Table 1

Death, unworked-through grief, separations and losses are themes that are present in the discourse and the life experiences of the patients that were significant and related to the event, both the AMI and the BC.

Only two patients did not associate grief for a lost loved one, a significant loss, to the illness; one associated it to the loss of the rich time of childhood, symbolically the "death" of her childhood, because she had to work from an early age to help her mother. And another one associated it to her father's abandonment of her, which felt as if her heart was slashed.

In a research performed by Rushel [53], heart attack patients mentioned unworked-through grief due to the death of family members as one of the causes of their illness. Faced with the loss of loved ones, the grief is repressed and the grieving may become chronic. The non-developed grieving constitutes a risk factor for infarction in the research participants.

\section{Discussion}

The attempt to symbolically comprehend what the illness brings to the patients' life, which associations are made in regards to the pathologies and the meaning they give to the illness, can offer a healing effect, a transforming effect, especially when worked therapeutically. Studies show the importance for women to seek awareness of the problem [17], as well as to seek a meaning of illness in women with coronary heart disease [16].

\section{Conclusions}

Through the analysis of the interviews given by the seven patients of the research and the symbols present in the drawings of the first three patients, we see models and demands from hypermodern society for hyperformance and

Table 1. Patient's fictitious names, age, marital status, type of surgery and life events considered traumatic and contributing to the process of illness.

\begin{tabular}{|c|c|c|c|c|c|c|}
\hline Number & Patients & Age & Marital status & Heart surgery & Breast surgery & Traumatic life events \\
\hline 1 & Lena & 60 & Divorced & $\mathrm{x}$ & $\mathrm{x}$ & $\begin{array}{l}\text { Divorce; death of a 2nd boyfriend; } \\
\text { abandonment of a 3rd boyfriend }\end{array}$ \\
\hline 2 & & 58 & Married & & $\mathrm{x}$ & Death of a son age 21 \\
\hline 3 & Fatima & 49 & Married & $\mathrm{x}$ & & Death of a sister age 5 \\
\hline 4 & Sofia & 68 & Married & & $\mathrm{x}$ & Hard work from a young age \\
\hline 5 & Cristal & 36 & Single & & $\mathrm{x}$ & Father left home when she was 4 \\
\hline 6 & Marina & 74 & Widow & Takotsubo & & Death of a husband \\
\hline 7 & Vivian & 42 & Divorced & $\mathrm{x}$ & & Divorce; death of a father when she was 14 \\
\hline
\end{tabular}


overachievement connected to the illness, when they are in excess. The illusion of the hero about strength and immortality, conscious or unconscious, was also seen. The experience of death, separation and loss, and without imaginable possibilities for working through revealed themselves as the most difficult experiences in the patients' lives, causing stress, weakness and decrease in the immunological system's capacity to react. However, the strength of the archetype of the hero appears strongly and intensely during the hospitalization period and follows the patients during their life and death trajectories [54].

The death of a loved one is a difficult issue to accept, as well as dealing with the idea of their own death, especially in Western society, where the difficulties with death are visible in the posture that reject the ultimate limit represented by old-age and finitude.

The post-surgery period is a time for reflection about life and death. Life reemerges with intensity, and the desire to live and enjoy life to the fullest is present. Death becomes, basically, a symbol of transformation. It now guides emotions and ideas, the projects and changes that are needed at that moment and for the future. It is when the desire for immortality leads us beyond human limitations.

"Human beings have an urgency to overcome limitations. This urgency is archetypal, ancestral and has been present in the collective psyche for millennia. Myths and also our clinical experience show us that the mythical heroes of all times, and also ordinary men, are always trying to overcome their limitations, the "metron", the measure imposed by the limitations, which include limitations of time, speed, beauty and youth, strength, intellectual ability, age, etc. However, the biggest limitation is death itself." [54].

The threat of death that has installed itself in the psyche of the patients due to their illness makes unconscious contents emerge, appearing as complexes that may aid in the psychic restructuring and the search for a greater emotional equilibrium. The reflections produced important transformations through the closer contact with themselves and reality.

We can also observe aspects that suggest a positive or negative prognosis in the psychic/emotional field, based on the ability or inability for personal structuring to face the illness, the shadow of death, the treatment and a new life. With these observations, it is important to suggest therapeutic work, whenever needed.

Observing our mental lives, Freud [55] states that prehistoric man survives unaltered in our unconscious, and also that "our unconscious does not believe in its own death; it behaves as if it were immortal" [55]. "Deep down, no one believes in their own death, all of us are unconsciously convinced of our own immortality" [55].

These statements show how hard it is for a Western person to think or even face their own death. "The unconscious seems not to recognize death" [56]. Nevertheless, Jung [57] observes that, psychologically, death is as important as birth, and therefore is an integral part of life.

In Eastern society, we see a more natural posture with regards to death, expressed in fragments from a poem of the Indian writer and poet Tagore [58], who received the Nobel Prize for Literature in 1913: "Death belongs to life as birth does. The walk is in the raising of the foot as in the laying of it down." (Stray Birds, CCXVI. Reflections)

West and East, regarding aspects of life and death, are two watchful perspectives in the field of health care. We suggest studies that approach the human dimension in its whole, broaching postures from both western and eastern societies in its specificities, with regard to the human experiences of suffering, illness, the emotions and considerations when faced with their own finitude.

\section{Ethical Aspects}

This study is the result of a PhD research developed at the FCM, UNICAMP. The project was approved by the Research Ethics Committee of the UNICAMP/FCM, Faculdade de Ciências Médicas, UNICAMP (UNICAMP Faculty of Medical Sciences, Protocol CAAE 0868.0.146.000-08. Protocol approved by the CEP, 01/26/2009. FR 1099/2008.

\section{References}

[1] Aubert, N. (2006) L'individu hypermoderne: Une mutation anthropologique? In: Molénat, X., Ed., L'individu contemporain, Regards sociologiques, Auxerre, Vol. 343, Editions Sciences Humaines, France, 155-166.

[2] Aubert, N. (2004) L'individu hypermoderne. Editions Erès, Paris.

[3] Aubert, N. (2004) Intensité de soi, incandescence de soi. In: Benoit, H., Org., La Performance, une nouvelle idéologie? La Découverte, Paris, 81-86.

[4] Aubert, N. (2003) Le culte de l'urgence. La société malade du temps. Flammarion, 331-337. 
[5] Littman, A.B., Fava, M., Halperin, P., Lamon-Fava, S., Drews, F.R., Oleshansky, M.A., Bielenda, C.C. and MacLaughlin, R.A. (1993) Physiologic Benefits of a Stress Reduction Program for Healthy Middle-Aged Army Officers. Journal of Psychosomatic Research, 37, 345-354. http://dx.doi.org/10.1016/0022-3999(93)90136-4

[6] Woodward, M., Oliphant, J., Lowe, G. and Tunstall-Pedoe, H. (2003) Contribution of Contemporaneous Risk Factors to Social Inequality in Coronary Heart Disease and All Causes Mortality. Preventive Medicine, 36, 561-568. http://dx.doi.org/10.1016/S0091-7435(03)00010-0

[7] Billings, R.F., Kearns, P.M. and Levene, D.L. (1981) The Influence of Psychological Factors on Chest Pain Associated with Myocardial Infarction. Acta Medica Scandinavica Supplementum, 644, 46-48.

[8] Fox, B.H., Ragland, D.R., Brand, R.J. and Rosenman, R.H. (1987) Type a Behavior and Cancer Mortality. Theoretical Consideration and Preliminary Data. Annals of the New York Academy of Sciences, 496, 620-627.

[9] Delamater, A.M., Albrecht, R., Smith, J.A. and Strube, M. (1989) Cardiovascular Correlates of Type: A Behavior Components during Social Interaction. Journal of Psychosomatic Research, 33, 641-650. http://dx.doi.org/10.1016/0022-3999(89)90071-8

[10] Engebretson, T.O. and Matthews, K.A. (1992) Dimensions of Hostility in Men, Women and Boys: Relationships to Personality and Cardiovascular Responses to Stress. Psychosomatic Medicine, 54, 311-323. http://dx.doi.org/10.1097/00006842-199205000-00007

[11] Mosley, T.H., Payne, T.J., Plaud, J.J., Johnson, C.A., Wittrock, D.A., Seville, J.L., Penzien, D.B. and Rodriguez, G. (1996) Psychometric Properties of the Weekly Stress Inventory (WSI): Extension to a Patient Sample with Coronary Heart Disease. Journal of Behavioral Medicine, 19, 273-287. http://dx.doi.org/10.1007/BF01857769

[12] Lemogne, C., Nabi, H., Zins, M., Cordier, S., Ducimetière, P., Goldberg, M. and Consoli, S. (2010) Hostility May Explain the Association between Depressive Mood and Mortality: Evidence from the French GAZEL Cohort Study. Psychotherapy and Psychosomatics, 79, 164-171.

[13] Consoli, S.M. (2003) Depression and Associated Organic Pathologies, a Still under-Estimated Comorbidity. Results of the DIALOGUE Study. Presse Medicale, 32, 10-21.

[14] Everson-Rose, S.A. and Lewis, T.T. (2005) Psychosocial Factors and Cardiovascular Diseases. Annual Review of Public Health, 26, 469-500. http://dx.doi.org/10.1146/annurev.publhealth.26.021304.144542

[15] Silveira, F.R., Miguel, J. and Oliveira, E. (2005) Síndrome Coronariana Isquêmica Aguda com Supradesnível do Segmento ST-Diagnóstico e tratamento Clínico. In: Pádua Filho, W., Barbosa, M.M. and Chula, E.D., Eds., Cardiologia: Sociedade Mineira de Cardiologia, Rio de Janeiro, Guanabara, 209.

[16] Rosenfeld, A.G. and Gilkeson, J. (2000) Meaning of Illness for Women with Coronary Heart Disease. Heart \& Lung, 29, 105-112.

[17] Higgins, M., Dunn, S. and Theobald, K. (2000) The Patient's Perception of Recovery after Coronary Angioplasty. Australian Critical Care, 13, 83-88. http://dx.doi.org/10.1016/S1036-7314(00)70629-1

[18] Lukkarinen, H. and Kyngäs, H. (2003) Experiences of the Onset of Coronary Artery Disease in a Spouse. European Journal of Cardiovascular Nursing, 2, 189-194. http://dx.doi.org/10.1016/S1474-5151(03)00062-8

[19] Jiang, W., Babyak, M., Krantz, D.S., Waugh, R.A., Coleman, R.E., Hanson, M.M., Frid, D.J., McNulty, S., Morris, J.J., O'Connor, C.M. and Blumenthal, J.A. (1996) Mental Stress-Induced Myocardial Ischemia and Cardiac Events. JAMA, 275, 1651-1656. http://dx.doi.org/10.1001/jama.1996.03530450041030

[20] Dimsdale, J.E. (2009) Psychological Stress and Cardiovascular Disease. Journal of the American College of Cardiology, 53, 1339. http://dx.doi.org/10.1016/j.jacc.2009.01.034

[21] Bosma, H., Peter, R., Siegrist, J. and Marmot, M. (1998) Two Alternative Job Stress Models and the Risk of Coronary Heart Disease. American Journal of Public Health, 88, 68-74. http://dx.doi.org/10.2105/AJPH.88.1.68

[22] Peter, R. and Siegrist, J. (2000) Psychosocial Work Environment and the Risk of Coronary Heart Disease. International Archives of Occupational and Environmental Health, 73, S41-S45. http://dx.doi.org/10.1007/PL00014625

[23] Hayano, J., Kimura, K., Hosaka, T., Shibata, N., Fukunishi, I., Yamasaki, K., Mono, H. and Maeda, S. (1997) Coronary Disease-Prone Behavior among Japanese Men: Job-Centered Lifestyle and Social Dominance. American Heart Journal, 134, 1029-1036. http://dx.doi.org/10.1016/S0002-8703(97)70022-X

[24] Dubourdieu, M. (2008) Psicoterapia Integrativa PNIE. Psiconeuroinmunoendocrinología. Integración Cuerpo-MenteEntorno. Psicolibros Waslala, Montevideo.

[25] Volmer, M.C. (2000) Bases da Psiconeuroinmuno-Endocrinologia. Buenos Aires, Salerno.

[26] Woodward, M., Oliphant, J., Lowe, G. and Tunstall-Pedoe, H. (2003) Contribution of Contemporaneous Risk Factors to Social Inequality in Coronary Heart Disease and All Causes Mortality. Preventive Medicine, 36, 561-568.

[27] Caprarulo, H. (2006) El Estrés. Pandemia del Siglo XXI. Psiconeuroinmunoendocrinología. Librería Akadia Editorial, Buenos Aires. 
[28] Vidal y Benito, M.C. (2008) Psiquiatría y Psicología del Paciente con Cáncer. Polemos, Buenos Aires.

[29] Lopez-Mato, A.M. (2004) Psiconeuroinmunoendocrinología II. Nuevos dilemas para viejos paradigmas. Viejos dilemas para neoparadigmas. Polemos, Buenos Aires.

[30] Laham, M.A. (2001) Psicocardiologia: Abordaje psicológico al paciente cardíaco. Ediciones Lumiere S.A., Buenos Aires.

[31] Marques-Deak, A. and Sternberg, E. (2004) Psiconeuroimunologia-A relação entre o sistema nervoso Central e o sistema imunológico. Revista Brasileira de Psiquiatria, 26, 143-144. http://dx.doi.org/10.1590/S1516-44462004000300002

[32] Messina, G., Lissoni, P., Bartolacelli, E., Magotti, L., Clerici, M., Marchiori, P. and Colombo, E. (2010) Relationship between Psychoncology and Psychoneuroendocrinoimmunology (PNEI): Enhanced T-Regulatory Lymphocyte Activity in Cancer Patients with Self-Punishment, Evaluated by Rorschach Test. In Vivo, 24, 75-78.

[33] Perdicaris, A. (2007) Além do Bisturi. Novas fronteiras na comunicação médica. Editora Universitária Leopoldianum, Santos.

[34] Reynaert, C., Libert, Y. and Pascal, J. (2000) Psychogenèse Du câncer: Entre mythes, abus ET réalité. Bulletin Du Cancer, 87, 655-664.

[35] Pavanello, R. (2009) O aumento do infarto agudo do miocárdio em jovens. Informe. http://www.hcor.com.br/Portals/_default/Skins/HCor/R bordo/OAumentodoInfartodoMiocardioemJovens.pdf

[36] Chagas, A.C.P. (2009) Hospital do Coração: Medicina de Excelência. Informe. http://www.hcor.com.br/Portals/ default/Skins/HCor/R bordo/HCORMEDICINAEXELENCIA.pdf

[37] Netto, C.G. (2007) Tratando (e prevenindo) o câncer hereditário. Jornal da Unicamp, 372, 17-23.

[38] Tessaro, S. and Brezolin, R. (2006) Epidemiologia do câncer de mama. In: Boff, R. and Wisintainer, F., Eds., Mastologia Moderna. Abordagem multidisciplinar, Mesa-Redonda, Caxias do Sul-RS.

[39] Consoli, S.M., Cordier, S. and Ducimetière, P. (1993) Validation of a Personality Questionnaire Designed for Defining Subgroups at Risk for Ischemic Cardiopathy or Cancer in the Gazel Cohort. Rev Epidemiol Sante Publique, 41, 315 326.

[40] Turato, E.R. (2008) Tratado da metodologia da pesquisa clínico-qualitativa. Construção teórico-epistemológica, discussão comparada e aplicação nas áreas da saúde e humanas, Vozes, Petrópolis, 246.

[41] Trinca, W. (1997) Formas de Investigação Clínica em Psicologia. Vetor, São Paulo.

[42] Tsuchihashi, K., Ueshima, K., Uchida, T., Oh-mura, N., Kimura, K., Owa, M., Yoshiyam, M., Miyazak, S., Haze, K., Ogawa, H., Honda, T., Hase, M., Kai, R. And Morii, I. (2001) Transient Left Ventricular Apical Ballooning without Coronary Artery Stenosis: A Novel Heart Syndrome Mimicking Acute Myocardial Infarction. Angina Pectoris-Myocardial Infarction Investigations in Japan. Journal of the American College of Cardiology, 38, 11-18.

http://www.ncbi.nlm.nih.gov/pubmed/11451258 http://dx.doi.org/10.1016/s0735-1097(01)01316-x

[43] Sato, H., Tateishi, H. and Uchida, T. (1990) Takotsubo-Type Cardiomyopathy due to Multivessel Spam. In: Kodama, K., Haze, K. and Hon, M., Eds., Clinical Aspects of Myocardial Injury: From Ischemia to Heart Failure, Kagakuhyouronsya Publishing Corporation, Tokyo, 56-64.

[44] Paiva, A.S. (2014) Corações Hipermodernos: Um estudoqualitativo realizado com mulheres atendidas em serviços privados no Brasil sobre eventos de vida, traços de personalidade e os sentidos e significados atribuídos ao infarto do miocárdio e ao câncer de mama. Ph.D. Thesis, Universidade Estadual de Campinas, UNICAMP, São Paulo, Campinas.

[45] Bardin, L. (1977) Análise de Conteúdo. Edições, Lisboa, 70.

[46] Trinca, W. (1984) Processo Diagnóstico de Tipo Compreensivo. In: Trinca, W., Org., Diagnóstico Psicológico: A Prática Clínica, E.P.U, São Paulo, 14-24.

[47] Brandão, J.S. (1988) Greek Mythology Course. Rio de Janeiro, from February to December of 1988. [Class Notes]

[48] Buffolo, E. and Gerola, L.R. (1997) Coronary Artery Bypass Grafting without Cardiopulmonary Bypass through Sternotomy and Minimally Invasive Procedure. International Journal of Cardiology, 62, S89-S93. http://dx.doi.org/10.1016/s0167-5273(97)00219-2

[49] Buffolo, E., Andrade, J.C.S., Branco, J.N.R., Teles, C., Gomes, W.J., Aguiar, L.F. and Palma, J.H. (1996) Revascularização do miocárdio sem circulação extracorpórea: Análise dos resultados em 15 anos de experiência. Revista Brasileira de Cirurgia Cardiovascular, 11, 227-231. http://dx.doi.org/10.1590/S0102-76381996000400002

[50] Buffolo, E., Branco, J.N., Gerola, L.R., Aguiar., L.F., Teles, C.A., Palma, J.H. and Catani, R. (2006) Off-Pump Myocardial Revascularization: Critical Analysis of 23 Years Experience in 3866 Patients. Annals of Thoracic Surgery, 81, 85-89. http://dx.doi.org/10.1016/j.athoracsur.2005.07.032 
[51] Lourenço, G., Cardoso-Filho, C., Gonçalves, N.S.L., Shinzato, J.Y., Zeferino, L.C., Nascimento, H., Costa, F.F., Gurgel, M.S.C. and Lima, C.S.P. (2006) A High Risk of Occurrence of Sporadic Breast Cancer in Individuals with the $104 \mathrm{NN}$ Polymorphism of the $C O L_{1} 8 A_{l}$ Gene. Breast Cancer Research and Treatment, 100, 335-338. http://dx.doi.org/10.1007/s10549-006-9259-z

[52] Lima, C.S.P. (2010) Modalidades terapêuticas em câncer. Boletim da FCM, 6, 4.

[53] Rushel, P.P. (2006) Quando o luto adoece o coração: luto não elaborado e infarto. EDIPUCRS, Porto Alegre.

[54] Paiva, S.A. (2002) Mito: Salvar Sempre? Os Limites do Humano. Revista de CARDIOLOGIA—Órgão de Divulgação Científica da Sociedade Brasileira de Cardiologia/MG Sociedade Mineira de Cardiologia. Suplemento Especial Aspectos Psicológicos e Cardiologia, 8, 29-30.

[55] Freud, S. (1969) Reflexões para os Tempos de Guerra e Morte. In: Freud, S., Ed., Edição Standard brasileira das obras psicológicas completas de Sigmund Freud: Vol. 14: História do movimento psicanalítico, artigos sobre metapsicologia e outros trabalhos, Imago, Rio de Janeiro, 327-335.

[56] Jung, C.G. (1977) A Entrevista "Face a Face”. In: Hull, R.F.C., McGuire, W.C.G. Jung: Entrevistas e Encontros, Cultrix, São Paulo, 383.

[57] Freeman, J. (1959) Face to Face with Carl Jung: Man Cannot Stand a Meaningless Life. Film-Video, BBC, Küsnacht.

[58] Tagore, R. (1995) Stray Birds, CCXVI. Reflections. Un Encuentro con Rabindranath Tagore: El Supremo Bien. Editorial Lumen, Buenos Aires, 37. 